\title{
Habitat prediction model for three-toed woodpecker and its implications for the conservation of biologically valuable forests
}

\author{
Krystyna Stachura-Skierczyńska a , Tomasz Tumiel ${ }^{\text {b }}$, Michał Skierczyński ${ }^{\text {c,* }}$ \\ a Polish Society for the Protection of Birds (OTOP), Odroważa 24, PL-05-270 Marki k. Warszawy, Poland \\ ${ }^{\mathrm{b}}$ Knyszyńska Forest - Important Bird Area (IBA) Caretaker, Towarowa 2A/48, PL-15-007 Białystok, Poland \\ ${ }^{\mathrm{c}}$ Department of Behavioural Ecology, Institute of Environmental Biology, Faculty of Biology, Adam Mickiewicz University, Umultowska 89, PL-61-614 Poznań, Poland
}

A R T I C L E I N F O

\section{Article history:}

Received 22 December 2008

Received in revised form 5 May 2009

Accepted 8 May 2009

\section{Keywords:}

Three-toed woodpecker

Habitat selection

Forest management

Biologically Important Forests

Maxent model

\begin{abstract}
A B S T R A C T
We studied habitat selection of three-toed woodpecker (TTW) in relation to forest structural variables, habitat types and hydrological conditions in north-eastern Poland. Based on known locations of 34 breeding pairs and the data on location of forest areas with high conservation value (referred to as Biologically Important Forests), we created a habitat prediction model for TTW using a Maxent algorithm. We found that this species most often selected breeding sites characterized by high contribution of old-growth stands with uneven vertical structure and considerable amount of very old trees of previous generations, as well as boreal spruce-dominated bogs and riverine forests. Such sites were preferred regardless of their actual protection status, which leads to the following conclusion: although existing forest reserves are very important to three-toed woodpecker, suitable habitats with similar characteristics can still be found outside protected areas and are also utilized by the species. However, such sites outside reserves are threatened by fragmentation due to timber extraction. Therefore it is recommended to protect these sites by either including them into existing reserves or putting them under special management schemes.

The presented model can be applied in similar environmental conditions across lowland Europe, allowing for identification of representative habitat network for future conservation planning at landscape scale.
\end{abstract}

๑) 2009 Elsevier B.V. All rights reserved.

\section{Introduction}

The three-toed woodpecker (TTW) Picoides tridactylus is widely recognized as a prey specialist, strongly dependent on habitats where the sufficient amount of insects living on recently dead conifers can be found (Mikusiński and Angelstam, 1998; Mikusiński et al., 2001; Angelstam et al., 2003; Roberge et al., 2008). The occurrence of TTW can be positively related with forest disturbances such as fire or wind falls (Fayt, 2003a), as well as with presence of old-growth stands with their natural dynamics. TTW is regarded as an indicator species for a guild of organisms dependent on dead wood (Roberge and Angelstam, 2006). Additionally, like other woodpecker species, it has a keystone value as a provider of cavities for secondary users. Finally, TTW plays particularly important role while considering economical aspects of forest management, due to its ability to control and limit bark beetle populations under epidemic levels (Fayt et al., 2005).

\footnotetext{
* Corresponding author. Tel.: +48 61829 5570; fax: +48 618295706 .

E-mail address: michskie@amu.edu.pl (M. Skierczyński).
}

According to available literature, both TTW subspecies (P.t. tridactylus: Pakkala et al., 2002; Fayt, 2003a,b; Bütler et al., 2004a and P.t. alpinus: Bütler et al., 2004a; Pechacek and d'OleireOltmanns, 2004; Pechacek, 2006) have been thoroughly studied, providing wide knowledge about species' habitat preferences. However, broader studies on the ecology of TTW population from the European lowland have been performed only in the unique conditions of Białowieża Primeval Forest, which cannot be compared to any other area in lowland part of Europe (Wesołowski and Tomiałojć, 1986; Wesołowski et al., 2005).

TTW, like other indicator species, is particularly suitable for habitat models due to its specific and well-defined requirements (Angelstam et al., 2004; Edenius and Mikusiński, 2006; RomeroCalcerrada and Luque, 2006). The TTW occurrence is correlated with presence of potentially valuable forest habitats; thus using it as a model-species provides efficient planning tool for management of such biologically important areas.

In this study we focus on two related aspects: (1) how to use the geographically oriented data on forest areas with high biological value in habitat prediction models for specialized woodpecker species, and (2) whether such models can be applied in practice as

0378-1127/\$ - see front matter (c) 2009 Elsevier B.V. All rights reserved. doi: $10.1016 /$ j.foreco.2009.05.007 
a basis for setting conservation targets in managed forest landscapes. The research was carried out in the Knyszyńska Forest (NE Poland), which represents an area of high biological value, but also a commercial forest with all aspects related to its productive functions; therefore our results can be implemented to other similar areas in lowland Europe.

\section{Material and methods}

\subsection{Study area}

Research was carried out in the Knyszyńska Forest $\left(1260 \mathrm{~km}^{2}\right)$ located in north-eastern Poland, a valuable breeding area of TTW, designated as an Important Bird Area and NATURA 2000 Special Protection Area (Sidło et al., 2004) (Fig. 1).

The forest landscape embraces broad river valleys, raised bogs and slight elevations. The dominant tree species are Scots pine Pinus silvestris and Norway spruce Picea abies; however, besides coniferous forest communities, broad-leaf and mixed stands are also present. In the past the Knyszyńska Forest was well connected to other large north-eastern European forests, but since the turn of the 18th-19th centuries the area has lost its linkages (Czerwiński, 1995). The best preserved fragments are located in 25 reserves totalling $49.7 \mathrm{~km}^{2}$ (3.9\% of Knyszyńska Forest area). However, only one of them $\left(3.1 \mathrm{~km}^{2}\right)$ is under strict protection. Outside protected areas, natural forest communities have been mostly replaced by planted stands revealing a simplified structure and altered tree species composition (Sokołowski, 2006). Clearcuts and intensive salvage cutting of spruce infested by the bark beetle Ips typographus are commonplace. Salvage cutting and sanitary measures are also practiced to some extent in nature reserves. Forest operations extend far into the bird breeding season.

\subsection{Bird data}

Data on TTW distribution was divided into two parts: (1) breeding pairs census within studied area carried out in years 20052007 (base locations), and (2) repeated census during verification of the model predictions in 2008 (new locations). Both censuses were done using the same method, in which census points were located inside potentially suitable TTW habitats, identified on the basis of known species' requirements. Woodpeckers were located using the playback stimuli during April and May. As many as 52 field visits were made, each one $6 \mathrm{~h}$ long on average. A single playback consists of 3-5 min of stimulation and $2 \mathrm{~min}$ of waiting for the response. Hearing points were located at least $500 \mathrm{~m}$ away from each other, in order to avoid double-counting the same individuals (Wesołowski et al., 2005; Tumiel, 2008). Feeding sites and other signs of woodpeckers' presence (spontaneous calling or drumming) were also recorded and checked. The breeding pair was defined according to the Polish Ornithological Atlas (PAO) criteria (PAO, 1986). To ensure that each site was occupied by a breeding pair, 2-4 control visits were conducted during one season. Each breeding pair was located on topographic map (1:25 000 scale) and the coordinates were imported into ArcGIS 9.x software.

\subsection{Environmental predictors}

The data on the forest age and structure was taken from Belarusian-Polish Forest Mapping (BPFM) database (Yermokhin et al., 2007). The BPFM project is a part of the wider mapping programme, Biologically Important Forests (BIF) Mapping, aimed to identify and map European forests revealing a high concentration of habitats valuable for biological diversity. BIFs can be represented by forest patches of any size, partially overlapping existing legally protected areas, designated NATURA 2000 sites and other valuable areas identified by various conservation initiatives, but also including forests selected on the basis of the project's specific criteria (Birdlife European FTF, 2008).

The information on BIFs was obtained mainly through the filtering of forest inventory database. The results were then associated with digital maps and transformed into generalized 25 ha grid (Yermokhin et al., 2007). For each 25 ha cell, the contribution of forest area meeting individual criteria was calculated (Table 1 ).

\subsection{Statistical analysis}

\subsubsection{Habitat selectivity}

We tested the model of habitat selection by woodpeckers based on comparison between the existing and randomly simulated populations. In this model TTW artificial locations were generated in random sequences within the study area with the average nearest distance between locations based on the data from existing populations $(N=34$, mean $=1876 \pm S E=198 \mathrm{~m})$. Random locations were generated using Hawth's Tools extension (Beyer, 2004) for ArcGIS 9.x. Data on forest parameters from the BPFM database was assigned both to existing and randomly generated locations. The differences between existing and simulated population were tested using a non-parametric Mann-Whitney U-test with Monte-Carlo exact test as a correction for random data (confidence level $=99 \%$, number of resamples $=10000$ ). All statistics were performed with SPSS 16.0 for Windows.

\subsubsection{Prediction model}

In the model we used 25 ha grid cells by following reasons: (1) we focus on the habitat in the neighbourhood of nest hole, since, as it was observed in the field, this core area is mainly used by foraging individuals and has the highest probability of encountering woodpeckers; (2) the spatial resolution of BPFM database used in this study amounts to 25 ha, which is a trade-off between the analysis efficiency and the accuracy appropriate for regional scale analysis; and (3) producing more coarse resolution from source data can reduce explanatory power of predicted model (Luoto et al., 2007).

Table 1

Environmental predictors used for the model design.

\begin{tabular}{|c|c|}
\hline Variable code & Description \\
\hline \multicolumn{2}{|c|}{ Forest structural dataset (Yermokhin et al., 2007) } \\
\hline NOACT & $\begin{array}{l}\text { Limited forestry actions; no timber extraction except for } \\
\text { occasional and sanitary cuts; areas designated as forest reserves }\end{array}$ \\
\hline OG & $\begin{array}{l}\text { Old-growth stands: stands over certain age } \\
\text { (specific age limit was set for each dominant species, } \\
\text { generally the stand was assumed as OG if it was } 20 \\
\text { years older than cutting age) }\end{array}$ \\
\hline STR1 & $\begin{array}{l}\text { Uneven age structure: age of trees in stand varies more } \\
\text { than } 30 \text { years and average stand age is more than } 80 \text { years }\end{array}$ \\
\hline STR2 & $\begin{array}{l}\text { Uneven canopy structure: presence of five or more species } \\
\text { in dominant canopy layer, at least } 50 \text { years old } \\
\text { (excluding understory) }\end{array}$ \\
\hline STR3 & $\begin{array}{l}\text { Very old trees present: presence of single trees over } 20 \text { years } \\
\text { of age limits set in criterion (OG) }\end{array}$ \\
\hline \multicolumn{2}{|c|}{ Forest habitat and hydrological dataset (Czerwiński, 1995) } \\
\hline BORBAG & Raised pine-bogs Vaccinio uliginosi-Pinetum, Ledo-sphagnetum \\
\hline BORMECH & Pine bogs Carici chordorrhizae-Pinetum \\
\hline BORPODM & $\begin{array}{l}\text { Wet and bog conifer-dominated communities on sandy or } \\
\text { dusty soils Myceli-Piceetum, Querco-Piceetum }\end{array}$ \\
\hline BORSWIER & Boreal spruce-dominated bogs Sphagno-piceetum \\
\hline BRZEZINA & Bog forests with birch Thelypteri-Betuletum \\
\hline GRUD & Mixed forests with spruce Tilio-Piceetum \\
\hline LEG & Riverine forests Circaeo-Alnetum, Fraxino-Ulmetum, Piceo-Alnetum \\
\hline OLS & Alder bogs Carici elongatae-Alnetum \\
\hline HYDRO & Hydrogenic area \\
\hline
\end{tabular}


We used Maxent 3.2.1 algorithm which has been recently adapted to the modelling of species distribution (Phillips, 2005, 2008; Phillips et al., 2006; Phillips and Dudík, 2008). This approach allows to find the probability distribution of maximum entropy (closest to the uniform) subject to the constraints imposed by the information available regarding the observed distribution of the species and the environmental conditions across the study area (Phillips et al., 2006). The method assigns an occurrence probability to each grid cell within the study area. The input data includes a set of grid layers with environmental variables for a geographical region and a set of species presence data within that region. Maxent assumes a priori an uniform distribution and performs a number of iterations in which the weights are adjusted to maximize the average probability of the point localities, expressed as the training gain (Phillips, 2005). These weights are then used to compute the Maxent distribution over the entire studied geographic space. Maxent can be applied to presence-only data to produce habitat suitability predictions as a function of corresponding environmental variables. Higher function values indicate more suitable conditions for the given species (Phillips, 2005). In this study we used logistic function to describe the habitat prediction model for the TTW within Knyszyńska Forest. The highest function value (close to 1 ) indicates the most suitable habitat conditions for studied species, in contradiction to unsuitable habitat indicated by the lowest value (close to 0 ). Being aware of the fact that environmental variables are usually correlated with each other, we used jackknife analysis (based on the area under the curve (AUC) of a receiver operating characteristic (ROC) plot for each environmental layer) to evaluate their significance as predictors in this model. Occurrence locations (the dependent variable) were randomly partitioned into two subsamples: $75 \%$ used as training dataset and the remaining $25 \%$ reserved for testing the resulting (partitioned) models. This can be interpreted as the probability that a presence site will be ranked above a random background site (Phillips et al., 2006; Phillips, 2008; Phillips and Dudík, 2008). A random ranking has a value of around 0.5 , while a perfect ranking achieves the maximum possible AUC of 1.0. Rankings with the AUC value above 0.75 are considered as potentially useful (Elith et al., 2006).

\section{Results}

\subsection{Habitat selection model}

While analysing the entire dataset for existing and simulated three-toed woodpecker populations, we found significant differences in almost all environmental predictors, except STR2, BORBAG, BORMECH and GRUD variables, that describe quite unique conditions, mostly limited to the reserves in the studied area. The greatest differences were observed between such environmental predictors as: limited forestry actions, presence of old-growth stands and flooded areas with riverine forest types (Table 2). We found no significant differences in all environmental predictors that characterized TTW breeding sites inside and outside forest reserves (Table 3). Based on direct observations, we observed that all of the TTW locations from existing population were associated with dead and/or decaying spruce trees and snags present in the field.

\subsection{Habitat prediction model}

The data used for preparing and testing of the prediction model for TTW appeared suitable and useful for Maxent analysis. The training AUC (0.976) and test AUC (0.955) were significantly different from random AUC (0.5) at a level of $p<0.001$. The performance of logistic output was significantly better than raw
Table 2

Comparison of forest structure variables between existing (TTW-N, N=34) and random locations (TTW-R, $N=34$ ) of three-toed woodpecker. Significant values are given in bold. See Table 1 for the variable definitions.

\begin{tabular}{lccrrr}
\hline Variable & \multicolumn{1}{l}{$\begin{array}{l}\text { TTW-N } \\
(\text { Mean } \pm \text { SE })\end{array}$} & $\begin{array}{l}\text { TTW-R } \\
(\text { Mean } \pm \text { SE })\end{array}$ & & $P$ value & $P$ value $^{*}$ \\
\hline NOACT & $36.7 \pm 8.0$ & $0.2 \pm 0.2$ & -3.858 & $<\mathbf{0 . 0 0 1}$ & $<\mathbf{0 . 0 0 1}$ \\
OG & $16.3 \pm 3.7$ & $3.1 \pm 2.0$ & -3.813 & $<\mathbf{0 . 0 0 1}$ & $<\mathbf{0 . 0 0 1}$ \\
STR1 & $15.3 \pm 4.0$ & $4.9 \pm 2.6$ & -2.806 & $\mathbf{0 . 0 0 5}$ & $\mathbf{0 . 0 0 5}$ \\
STR2 & $3.8 \pm 1.5$ & $3.7 \pm 1.9$ & -0.823 & 0.411 & 0.494 \\
STR3 & $11.9 \pm 3.8$ & $3.4 \pm 2.0$ & -2.500 & $\mathbf{0 . 0 1 2}$ & $\mathbf{0 . 0 1 1}$ \\
BORBAG & $0.4 \pm 0.4$ & $0.0 \pm 0.0$ & -1.000 & 0.317 & 1.000 \\
BORMECH & $2.8 \pm 2.8$ & $0.0 \pm 0.0$ & -1.000 & 0.317 & 1.000 \\
BORPODM & $4.3 \pm 1.7$ & $1.2 \pm 1.2$ & -2.277 & $\mathbf{0 . 0 2 3}$ & $\mathbf{0 . 0 2 9}$ \\
BORSWIER & $7.9 \pm 3.1$ & $0.8 \pm 0.8$ & -3.129 & $\mathbf{0 . 0 0 2}$ & $\mathbf{0 . 0 0 2}$ \\
BRZEZINA & $3.9 \pm 2.0$ & $0.0 \pm 0.0$ & -2.767 & $\mathbf{0 . 0 0 6}$ & $\mathbf{0 . 0 1 1}$ \\
GRUD & $1.3 \pm 1.2$ & $0.0 \pm 0.0$ & -1.425 & 0.154 & 0.490 \\
LEG & $14.1 \pm 3.7$ & $2.2 \pm 1.3$ & -2.928 & $\mathbf{0 . 0 0 3}$ & $\mathbf{0 . 0 0 2}$ \\
OLS & $22.0 \pm 4.7$ & $0.0 \pm 0.0$ & -5.691 & $<\mathbf{0 . 0 0 1}$ & $<\mathbf{0 . 0 0 1}$ \\
HYDRO & $54.6 \pm 6.7$ & $16.5 \pm 5.3$ & -4.228 & $<\mathbf{0 . 0 0 1}$ & $<\mathbf{0 . 0 0 1}$ \\
\hline
\end{tabular}

Monte-Carlo exact test.

\section{Table 3}

Comparison of forest structure variables between three-toed woodpecker locations inside (TTW-IN, $N=14$ ) and outside (TTW-OUT, $N=20$ ) reserves. See Table 1 for the variable definitions.

\begin{tabular}{lccccc}
\hline Variable & $\begin{array}{l}\text { TTW-IN } \\
(\text { Mean } \pm \text { SE })\end{array}$ & $\begin{array}{l}\text { TTW-OUT } \\
(\text { Mean } \pm \text { SE) }\end{array}$ & $Z$ & $P$ value & $P$ value \\
\hline OG & $19.7 \pm 7.7$ & $13.9 \pm 3.3$ & -0.110 & 0.913 & 0.931 \\
STR1 & $22.5 \pm 8.1$ & $10.3 \pm 3.6$ & -1.001 & 0.317 & 0.377 \\
STR2 & $2.3 \pm 1.8$ & $4.9 \pm 2.3$ & -0.792 & 0.428 & 0.592 \\
STR3 & $20.0 \pm 7.9$ & $6.2 \pm 2.8$ & -1.441 & 0.150 & 0.217 \\
BORBAG & $0.9 \pm 0.9$ & $0.0 \pm 0.0$ & -1.195 & 0.232 & 0.743 \\
BORMECH & $6.7 \pm 6.7$ & $0.0 \pm 0.0$ & -1.195 & 0.232 & 0.743 \\
BORPODM & $1.8 \pm 1.4$ & $6.3 \pm 2.7$ & -0.811 & 0.417 & 0.545 \\
BORSWIER & $9.5 \pm 6.1$ & $6.7 \pm 3.3$ & -0.295 & 0.768 & 0.823 \\
BRZEZINA & $7.7 \pm 4.6$ & $1.3 \pm 1.0$ & -1.782 & 0.075 & 0.217 \\
GRUD & $3.1 \pm 2.9$ & $0.0 \pm 0.0$ & -1.716 & 0.086 & 0.500 \\
LEG & $14.5 \pm 5.1$ & $13.9 \pm 5.3$ & -0.760 & 0.447 & 0.522 \\
OLS & $18.5 \pm 6.9$ & $24.4 \pm 6.4$ & -1.032 & 0.302 & 0.323 \\
HYDRO & $63.5 \pm 11.0$ & $48.4 \pm 8.3$ & -1.267 & 0.205 & 0.217 \\
\hline
\end{tabular}

Monte-Carlo exact test.

output when using random background $(Z=-13.318, p<0.001$, two-tailed Wilcoxon signed-rank test). The PCA analysis showed that environmental variables explained $71.7 \%$ of variance in the prediction model. A heuristic estimate of relative variable contributions implemented in Maxent, showed that the most important predictors were OLS (38.1\%), NOACT (24.2\%), BORSWIER $(12.2 \%)$ and OG $(9.6 \%)$ with cumulative $84.1 \%$ of share. As for the other predictors, the individual contribution in each case did not exceed 5\%. The jackknife analysis showed that the most important variables were BORSWIER, OLS and OG which represented the highest ACU values for the TTW habitat prediction (Fig. 2).

Considering the above facts, we created the predictive habitat map for TTW. According to the model, the optimal habitat was found in 256 cells of studied area (Fig. 3) and showed the highest probability for encountering TTW, varying from 0.31 to 0.98 . The suboptimal habitat was represented by 771 cells and showed lower probability of encountering TTW, varying from 0.11 to 0.30 (Fig. 3). Optimal habitats covered 3.9\% of Knyszyńska Forest, while the existing population utilizes merely $0.5 \%$ of the total forest area (34 cells).

\subsection{Model evaluation}

In 2008 another TTW census was conducted. We found 11 additional locations, including eight described as new locations (territorial birds observation) and three described as possible 


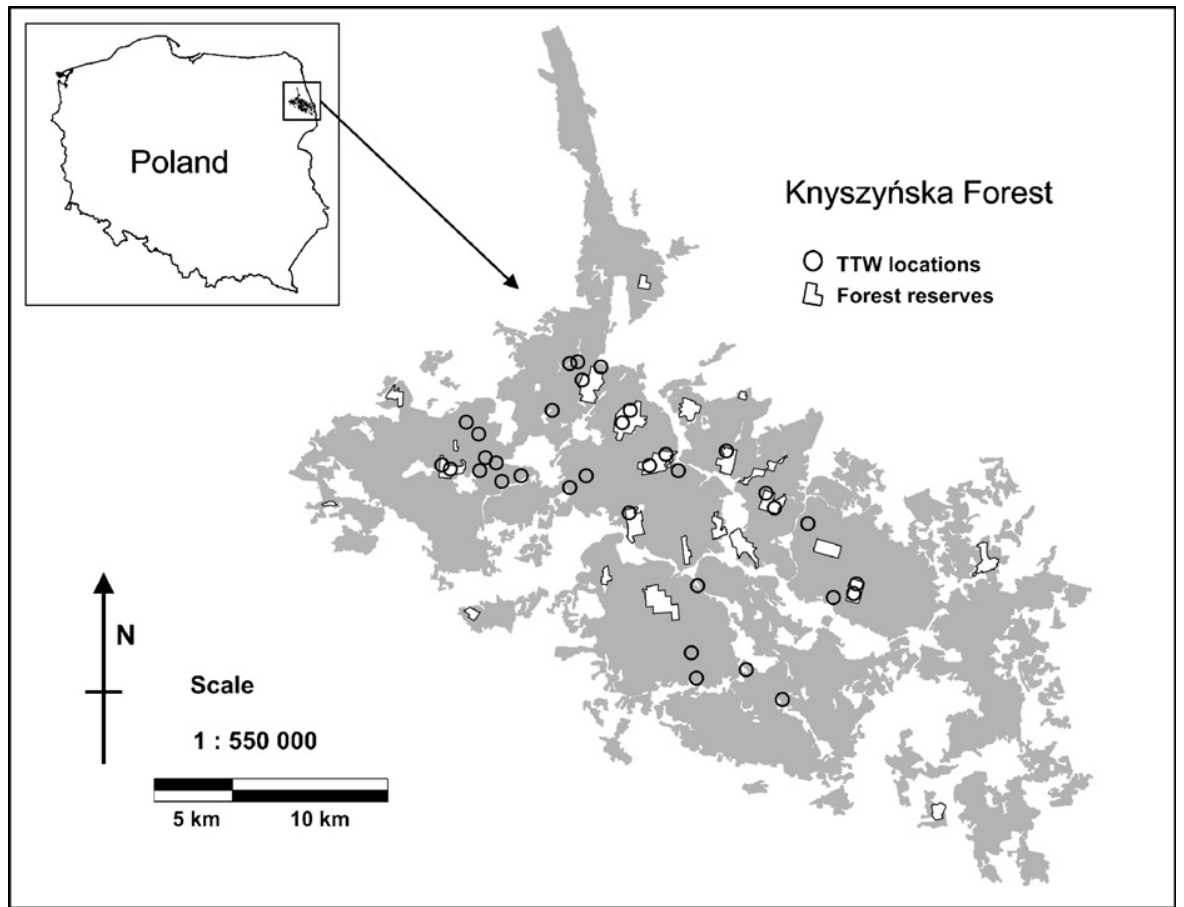

Fig. 1. Locations of studied three-toed woodpecker (TTW) population within Knyszyńska Forest and its reserves.

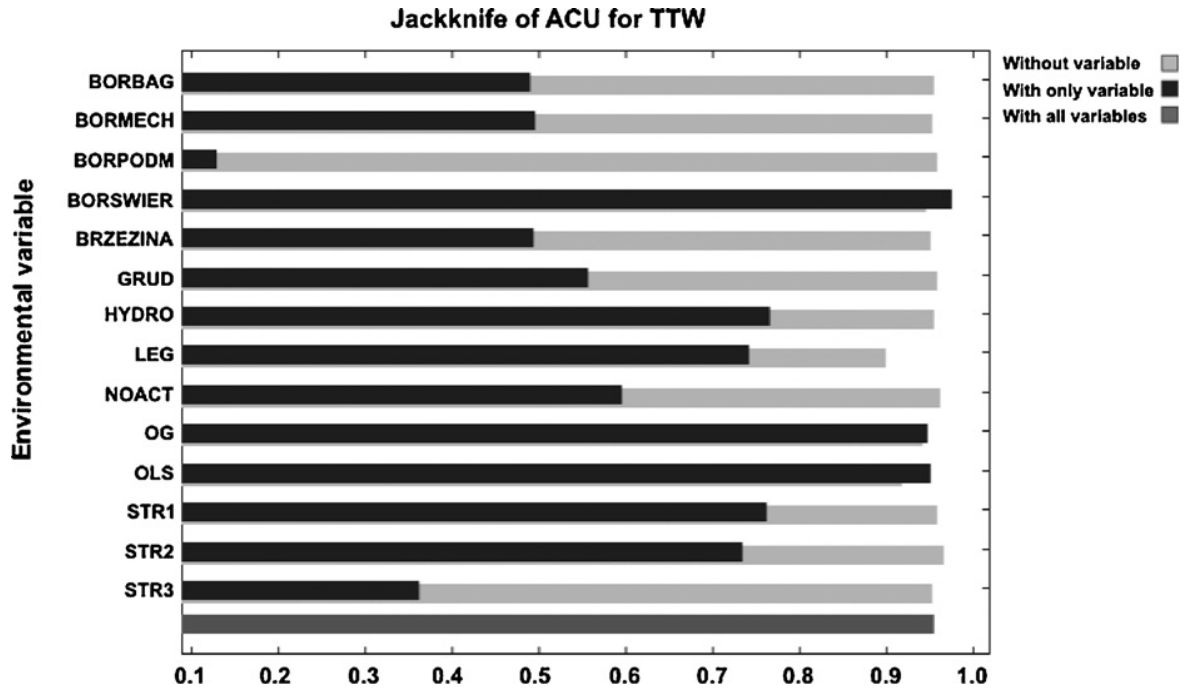

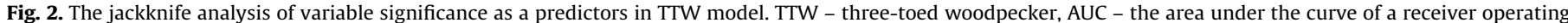
characteristic (ROC) plot.

locations (feeding sites, solitary birds without territorial behaviour). All these TTW locations were found in optimal $(N=7)$ and suboptimal $(N=4)$ habitats (Fig. 3$)$. It seems worth noticing that the majority of best predicted habitats for TTW (suitable and optimal) is located outside existing reserves: $51.4 \%$ (36 cells), $75.8 \%$ ( 138 cells) for suitable and optimal habitats respectively and $68.8 \%$ ( 176 cells) for both classes together (Table 4 ). To sum up, the area of best habitats remaining outside reserves makes $2.7 \%$ of total area of Knyszyńska Forest (Fig. 4).

\section{Discussion}

According to our research it can be concluded that TTW in north-eastern Poland prefers natural and seminatural old-growth stands with considerable amount of snags rather than managed, human altered forest habitats. Similar preferences were described for this species in another biologically important area in the region - the Białowieża Forest (Walankiewicz et al., 2002; Wesołowski et al., 2005) and also reported from a scope of various European TTW populations (Fayt, 2003a; Bütler et al., 2004a,b; Hanski and Walsh, 2004; Pechacek and d'Oleire-Oltmanns, 2004; Roberge et al., 2008).

TTW population in the Knyszyńska Forest was recently estimated by Tumiel (2008) at the level of 34 breeding pairs. Our results suggest that TTW population in studied area can be larger than what has been originally estimated. Considering the predicted amount of optimal habitat we estimate potential TTW population at the level of 50-60 breeding pairs. However, more research on TTW breeding success in optimal and suboptimal forest patches is needed. As far as we are concerned, there is no 


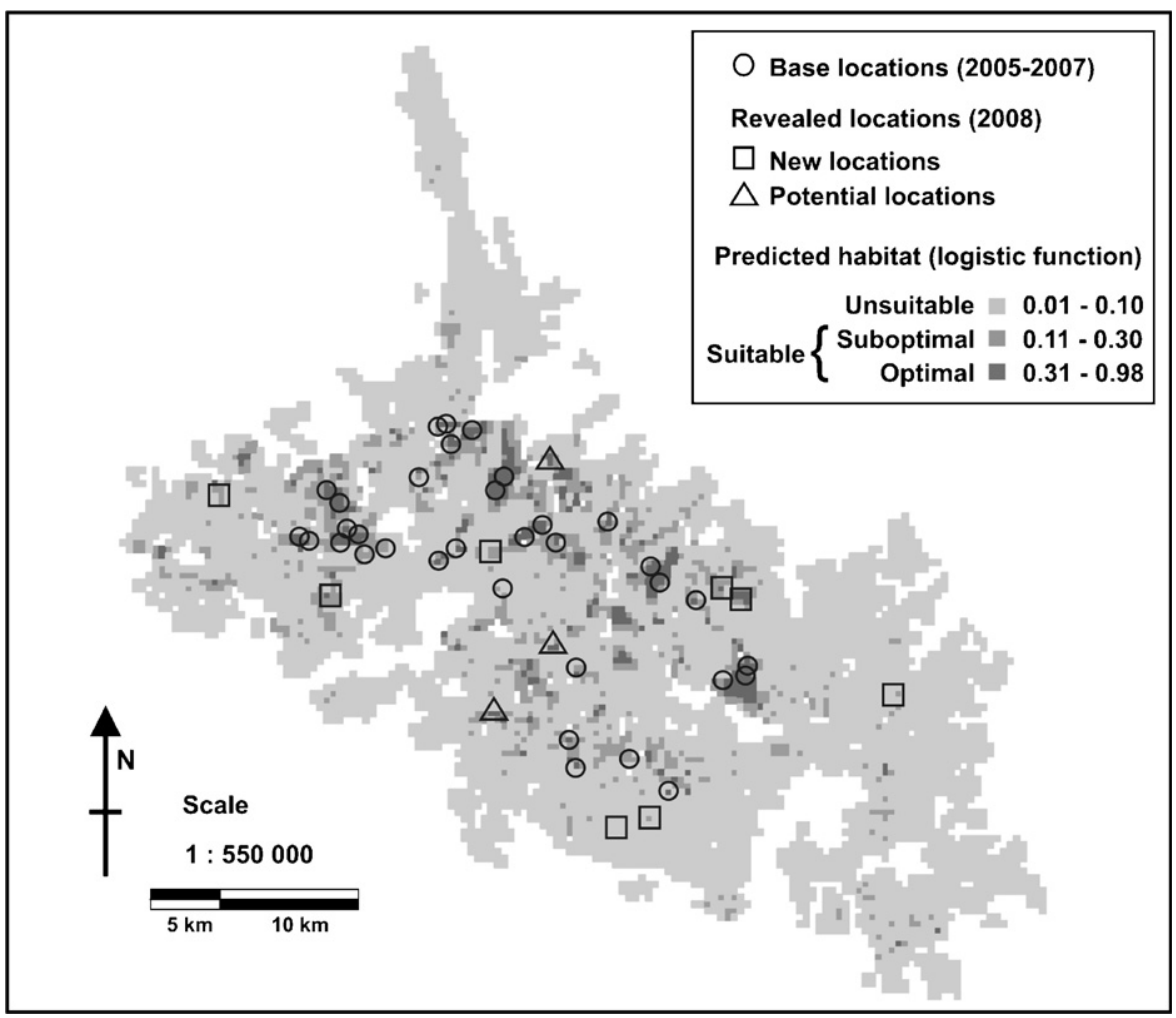

Fig. 3. Habitat prediction model for three-toed woodpecker in Knyszyńska Forest including TTW base and revealed locations. For description of base and revealed location see Section 2.2 .

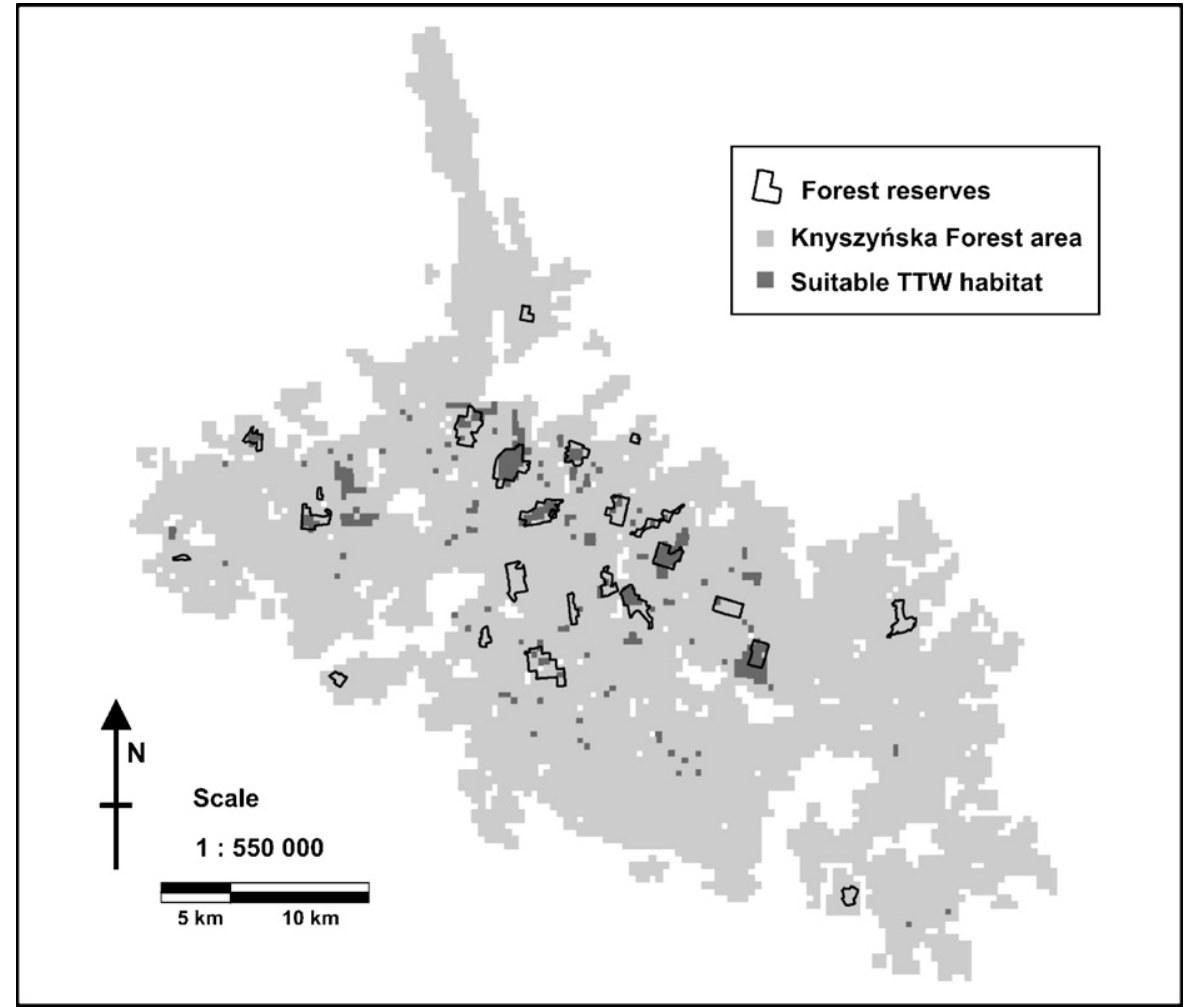

Fig. 4. Suitable and optimal TTW habitat inside and outside existing reserves within studied area.

sufficient data referring to the ability of studied Polish TTW populations to colonize new habitats that occur due to natural disturbances. On the contrary, such behavioural responses have been observed in North America, where TTW is able to recognize disturbed forests (i.e. burned areas) and colonize new habitats quite rapidly (Villard, 1994; Murphy and Lenhasuen, 1998; Hoyt and Hannon, 2002). This can also be true for western and northern European populations which are characterized by quite good natal

Please cite this article in press as: Stachura-Skierczyńska, K., et al., Habitat prediction model for three-toed woodpecker and its implications for the conservation of biologically valuable forests. Forest Ecol. Manage. (2009), doi:10.1016/j.foreco.2009.05.007 
dispersal patterns (Fayt, 2003b; Pechacek, 2006). On the other hand, while there are no suitable disturbances around, the species remains in old growths as well (Pakkala et al., 2002; Bütler et al., 2004a,b).

Another important fact is that 65\% of TTW locations (22 out of 34) were situated close to the European beaver Castor fiber settlements or areas flooded by beavers, especially riverine stands with alder and spruce (Tumiel, 2008). Therefore, we presume that the presence of beavers and their settlements can positively influence the long-term survival of TTW population, due to continuous supply of snags and dead wood and maintenance of suitable habitats. Those suggestions were also supported by our results, where we found that the presence of hydrogenic areas with riverine and alder bog forests was positively correlated with TTW occurence. Such coexistence of TTW and beavers was also recorded in Finland (Gorman, 2004) and North America (Short, 1974).

The relationship with stand vertical structure discovered in our study could be explained by the fact that the only remaining patches of suitable, dead wood-rich habitat were in natural stands, characterized by such diversed structure. No differences found in the STR2 structural variable can be explained by the feeding habits of TTW. This woodpecker is a prey specialist, searching for insects on snags of few tree species i.e. Norway spruce (Fayt, 1999, 2003a,b; Bütler et al., 2004b), therefore it does not depend on the stand species richness (an attribute described by the variable STR2).

Many of sites containing suitable TTW habitats remain unprotected at the moment. Clearcuts and sanitary felling practiced by the forest service contribute to the gradual loss of old-growth patches outside protected areas. Nevertheless, even the legal protection status of forest reserves does not prevent from removal of dying spruces. The importance of forest reserves for TTW in studied area is underlined by the fact that despite making up only $3.9 \%$ of total forest area they contained $41 \%$ of all TTW breeding pairs recorded during the study and similar findings were reported from this region of Poland also by Angelstam et al. (2002). However, only one of these reserves is strictly protected and the rest can be subjected to 'active protection' with all its consequences, i.e. sanitary cuttings. The lack of differences in forest structural variables between TTW nesting sites inside and outside reserves suggests two important conclusions: first, there are still sites characterized by similar features as nearly natural forests in reserves, but not protected at all; second, current conservation approach does not guarantee the preservation of all features typical for pristine, undisturbed forests. Nevertheless, it should be noticed that: (1) suitable habitats for TTW outside reserves are still quite rare, and not likely to be found by chance (see Table 2 for comparison), (2)

\section{Table 4}

Comparison of best predicted forest patches (suitable and optimal) inside (ForestIN, $N=40$ ) and outside (Forest-OUT, $N=40$ ) reserves. Significant values are given in bold. See Table 1 for the variable definitions.

\begin{tabular}{lcclrr}
\hline Variable & $\begin{array}{l}\text { Forest-IN } \\
(\text { Mean } \pm \text { SE) }\end{array}$ & $\begin{array}{l}\text { Forest-OUT } \\
(\text { Mean } \pm \text { SE) }\end{array}$ & & $P$ value & $P$ value \\
\hline OG & $16.6 \pm 3.3$ & $34.4 \pm 4.9$ & -2.839 & $\mathbf{0 . 0 0 5}$ & $\mathbf{0 . 0 0 2}$ \\
STR1 & $15.7 \pm 4.0$ & $28.3 \pm 5.5$ & -1.581 & 0.114 & 0.107 \\
STR2 & $1.4 \pm 0.6$ & $3.5 \pm 1.0$ & -1.574 & 0.116 & 0.109 \\
STR3 & $18.4 \pm 4.6$ & $6.1 \pm 1.4$ & -1.342 & 0.180 & 0.177 \\
BORBAG & $0.4 \pm 0.4$ & $0.1 \pm 0.1$ & -0.018 & 0.986 & 1.100 \\
BORMECH & $3.7 \pm 2.6$ & $0.0 \pm 0.0$ & -1.754 & 0.079 & 0.245 \\
BORPODM & $1.2 \pm 0.5$ & $5.2 \pm 1.7$ & -1.940 & 0.052 & $\mathbf{0 . 0 4 8}$ \\
BORSWIER & $3.6 \pm 1.7$ & $6.4 \pm 2.4$ & -0.639 & 0.523 & 0.524 \\
BRZEZINA & $12.6 \pm 4.0$ & $0.7 \pm 0.7$ & -3.509 & $<\mathbf{0 . 0 0 1}$ & $<\mathbf{0 . 0 0 1}$ \\
GRUD & $8.3 \pm 2.7$ & $2.1 \pm 1.4$ & -2.082 & $\mathbf{0 . 0 3 7}$ & $\mathbf{0 . 0 4 5}$ \\
LEG & $10.3 \pm 2.9$ & $8.2 \pm 2.6$ & -0.141 & 0.888 & 0.887 \\
OLS & $17.8 \pm 3.6$ & $10.7 \pm 2.5$ & -1.065 & 0.287 & 0.289 \\
HYDRO & $58.3 \pm 6.6$ & $50.8 \pm 7.0$ & -0.483 & 0.629 & 0.631 \\
\hline
\end{tabular}

Monte-Carlo exact test. moreover, suitable sites outside reserves are threatened by fragmentation due to commercial use for timber extraction.

We estimated the amount of most suitable TTW habitat remaining outside reserves as $2.7 \%$ of total area of Knyszyńska Forest. It is strongly recommended that biologically valuable sites occupied by TTW in managed forest are also preserved in the future. Moreover, in order to prevent the effects of fragmentation into small, isolated patches of protected forest unable to maintain the viable populations at the regional scale, these 'key habitats' should be surrounded by functional buffers and connectors. Forest management in these zones should be focused on maintaining continuous forest cover and preserving the presence of overmature trees and snags (Hanski and Walsh, 2004).

Despite the fact that unoccupied suitable habitats are still present, during field investigations we observed that they were subjected to regular sanitary cutting. As a result, the lack of key factor - old spruces, infested by bark beetle - prevents TTW from colonizing these sites. The conflict between biological and commercial values is a common problem in managed forest (see i.e. Wesołowski, 2005). Virkkala (2006) proposes the holistic approach: instead of costly and inefficient removal of infested trees, old-growth forests (preferred by i.e. three-toed woodpeckers) should be maintained and preserved in large enough quantities. Maintenance of viable populations of specific predators is an efficient way to solve the problem of pest control (Fayt et al., 2005). Allowing for natural processes in managed forests makes it possible to benefit from both timber extraction and nature protection (Virkkala, 2006).

\section{Conclusions}

The model presented above can be applied in other lowland European forests with similar environmental conditions, where data on TTW presence and location of Biologically Important Forests is available. What is more important, by applying models created for specialized forest-dwelling species, we are able to assess representative habitat networks for future direct conservation planning at landscape scale (Angelstam et al., 2004). As a result, we obtain a predictive map of new suitable habitat for considered species. In the next step, the locations of identified species-specific habitats should be compared with borders of existing protected areas (such as reserves). Such analysis enables to identify potential habitats that should be sustained in order to maintain the amount necessary for the survival of species population (Cowley et al., 2000) in that case for TTW.

\section{Acknowledgements}

We thank Marcus Walsh and Andrzej Bobiec for comments on the earlier draft of this manuscript and linguistic corrections. The Belarusian-Polish Forest Mapping (BPFM) was sponsored by Aage V. Jensens Fonde and conducted under supervision of Birdlife European Forest Task Force in 2005-2007.

\section{References}

Angelstam, P., Bütler, R., Lazdinis, M., Mikusinski, G., Roberge, J.M., 2003. Habitat thresholds for focal species at multiple scales and forest biodiversity conservation-dead wood as an example. Annales Zoologici Fennici 40, 473482.

Angelstam, P., Breuss, M., Mikusinski, G., Stenström, M., Stighäll, K., Thorell, D., 2002. Effects of forest structure on the presence of woodpeckers with different specialisation in a landscape history gradient in NE Poland. In: Chamberlain, D., Wilson, D. (Eds.), Avian Landscape Ecology. Proceedings of the 2002 Annual IALE (UK) Conference held in University of East Anglia. pp. 25-38.

Angelstam, P., Roberge, J.-M., Lõhmus, A., Bergmanis, M., Brazaitis, G., Dönz-Breuss, M., Edenius, L., Kosiński, Z., Kurlavicius, P., Lārmanis, V., Lūkins, M., Mikusinski, G., Račinskis, E., Strazds, M., Tryjanowski, P., 2004. Habitat modelling as a tool 
for landscape-scale conservation-a review of parameters for focal forest birds. Ecological Bulletins 51, 427-453.

Beyer, H.L., 2004. Hawth's Analysis Tools for ArcGIS. Available at http://www. spatialecology.com/htools.

Birdlife European FTF, 2008. Biologically Important Forests. Available at: http:// www.forestmapping.net/.

Bütler, R., Angelstam, P., Ekelund, P., Schlaepfer, R., 2004a. Dead wood threshold values for the three-toed woodpecker presence in boreal and sub-Alpine forest. Biological Conservation 119, 305-318.

Bütler, R., Angelstam, P., Schlaepfer, R., 2004b. Quantitative snag targets for the three-toed woodpecker Picoides tridactylus. Ecological Bulletins 51, 219-232.

Cowley, M.J.R., Wilson, R.J., Leon-Cortes, J.L., Gutierrez, D., Bulman, C.R., Thomas, C.D., 2000. Habitat-based statistical models for predicting the spatial distribution of butterflies and day-flying moths in a fragmented landscape. Journal of Applied Ecology 37, 60-72.

Czerwiński, A. (Ed.), 1995. Puszcza Knyszyńska. Monografia Przyrodnicza. Zespół Parków Krajobrazowych w Supraślu, Supraśl, p. 510 (in Polish).

Edenius, L., Mikusiński, G., 2006. Utility of habitat suitability models as biodiversity assessment tools in forest management'. Scandinavian Journal of Forest Research 21, 62-72.

Elith, J., Graham, C.H., Anderson, R.P., Dudík, M., Ferrier, S., Guisan, A., Hijmans, R.J., Huettmann, F., Leathwick, J.R., Lehmann, A., Li, J., Lohmann, L.G., Loiselle, B.A Manion, G., Moritz, C., Nakamura, M., Nakazawa, Y., McC. Overton, J., MOPeterson, A.T., Phillips, S.J., Richardson, K., Scachetti-Pereira, R., Schapire, R.E. Soberón, J., Williams, S., Wisz, M.S., Zimmermann, N.E., 2006. Novel methods improve prediction of species' distributions from occurrence data. Ecography 29, 129-151.

Fayt, P., 1999. Available insect prey in bark patches selected by the three-toed woodpecker Picoides tridactylus prior to reproduction. Ornis Fennica 76, 135140.

Fayt, P., 2003a. Population ecology of the three-toed woodpecker under varying food supplies. PhD Dissertation, University of Joensuu.

Fayt, P., 2003b. Time of natal dispersal and reproductive decisions of three-toed woodpecker Picoides tridactylus under varying food conditions. Forschungsbericht 48, Nationalparkverwaltung Berchtesgaden, pp. 35-48.

Fayt, P., Machmer, M.M., Steeger, C., 2005. Regulation of spruce bark beetles by woodpeckers-a literature review. Forest Ecology and Management 206, 1-14.

Gorman, G. (Ed.), 2004. Woodpeckers of Europe. Bruce Coleman Books, p. 192.

Hanski, I., Walsh, M., 2004. How Much, How To-Practical Tools for Forest Conservation. BirdLife European Forest Task Force, p. 50.

Hoyt, J.S., Hannon, S.J., 2002. Habitat associations of black-backed and three-toed woodpeckers in the boreal forest of Alberta. Canadian Journal of Forest Research 32, 1881-1888.

Luoto, M., Virkkala, R., Heikkinen, R.K., 2007. The role of land cover in bioclimatic models depends on spatial resolution. Global Ecology and Biogeography 16, 3442 .

Mikusiński, G., Angelstam, P., 1998. Economic geography, forest distribution, and woodpecker diversity in central Europe. Conservation Biology 18, 200-208.

Mikusiński, G., Gromadzki, M., Chylarecki, P., 2001. Woodpeckers as indicators of forest bird diversity. Conservation Biology 15, 208-217.

Murphy, E.C., Lenhasuen, W.A., 1998. Density and foraging ecology of woodpeckers following a stand-replacement fire. Journal of Wildlife Management 62, 13591372.

Pakkala, T., Hanski, I., Tomppo, E., 2002. Spatial ecology of the three-toed woodpecker in managed forest landscapes. Silva Fennica 36, 278-288.
Pechacek, P., 2006. Breeding performance, natal dispersal, and nest site fidelity of the three-toed woodpecker in the German Alps. Annales Zoologici Fennici 43 165-176.

Pechacek, P., d'Oleire-Oltmanns, W., 2004. Habitat use of the three toed woodpecker in central Europe during the breeding period. Biological Conservation 116, 333341.

Phillips, S.J., 2005. Maxent software for species distribution modelling. Available at http://www.cs.princeton.edu/ schapire/maxent/.

Phillips, S.J., Dudík, M., 2008. Modeling of species distributions with Maxent: new extensions and a comprehensive evaluation. Ecography 31, 161-175.

Phillips, S.J., 2008. Transferability, sample selection bias and background data in presence-only modelling: a response to Peterson et al. (2007). Ecography 31, 272-278.

Phillips, S.J., Anderson, R.P., Schapire, R.E., 2006. Maximum entropy modeling of species geographic distributions. Ecological Modelling 190, 231-259.

PAO, 1986. Polski Atlas Ornitologiczny. Instrukcja zapisu obserwacji i wypełniania formularzy atlasowych. Komunikat 2 (in Polish).

Romero-Calcerrada, R., Luque, S., 2006. Habitat quality assessment using weightsof-evidence based GIS modelling: the case of Picoides tridactylus as species indicator of the biodiversity value of the Finnish forest. Ecological Modelling $196,62-76$

Roberge, J.-M., Angelstam, P., 2006. Indicator species among resident forest birds-A cross-regional evaluation in northern Europe. Biological Conservation 130, 134-147.

Roberge, J.-M., Angelstam, P., Villard, M.-A., 2008. Specialised woodpeckers and naturalness in hemiboreal forests-deriving quantitative targets for conservation planning. Biological Conservation 141, 997-1012.

Short, L.L., 1974. Habitat and interactions of North American three-toed woodpeckers (Picoides arcticus and Picoides tridactylus). American Museum Novit 2547, $1-42$

Sidło, P.O., Błaszkowska, B., Chylarecki, P. (Eds.), 2004. IBAs of EU Importance in Poland. OTOP, Warszawa, p. 673 (in Polish with English summary).

Sokołowski, A.W., 2006. Przyroda województwa podlaskiego i jej ochrona. Łomżyńskie Towarzystwo Naukowe im, Wagów, p. 336 (in Polish).

Tumiel, T., 2008. Liczebność i rozmieszczenie dzięcioła trójpalczastego Picoides tridactylus w Puszczy Knyszyńskiej w latach 2005-2007. Notatki Ornitologiczne 49, 74-80 (in Polish with English summary).

Villard, P., 1994. Foraging behavior of black-backed and three-toed woodpeckers during spring and summer in a Canadian boreal forest. Canadian Journal of Zoology 72, 1957-1959.

Virkkala, R., 2006. Why study woodpeckers? The significance of woodpeckers in forest ecosystems. Annales Zoologici Fennici 43, 82-85.

Walankiewicz, W., Czeszczewik, D., Mikrus, C., Bida, E., 2002. Znaczenie martwych drzew dla zespołu dzięciołów w lasach liściastych Puszczy Białowieskiej-in Polish with English summary. Notatki Ornitologiczne 43, 61-71.

Wesołowski, T., 2005. Virtual conservation: how the European Union is turning a blind eye to its vanishing primeval forests. Conservation Biology 19, 1349-1358.

Wesołowski, T., Tomiałojć, L., 1986. The breeding ecology of woodpeckers in a temperate primaeval forest-preliminary data. Acta Ornithologica 22, 1-22.

Wesołowski, T., Czeszczewik, D., Rowiński, P., 2005. Effect of forest management on three-toed woodpecker Picoides tridactylus in Białowieża Forest (NE Poland)conservation implications. Acta Ornithologica 40, 53-60.

Yermokhin, M., Stachura-Skierczyńska, K., Bobiec, A., Puhacheuski, A., Walsh, M. (Eds.), 2007. Belarusian-Polish Forest Mapping: Final Report, BirdLife European Forest Task Force. Available at http://www.forestmapping.net/. 